\title{
Article \\ Exogenous Application of Foliar Salicylic Acid and Propolis Enhances Antioxidant Defenses and Growth Parameters in Tomato Plants
}

\author{
Nouran Ahmed Abdo Abd El-Hady ${ }^{1}$, Abdelaleim Ismail ElSayed ${ }^{1}{ }^{(\mathbb{O}}$, Sayed Soliman El-saadany ${ }^{1}$, \\ Paola A. Deligios ${ }^{2}(\mathbb{D})$ and Luigi Ledda ${ }^{3, *(D)}$ \\ 1 Biochemistry Department, Faculty of Agriculture, Zagazig University, 44519 Zagazig, Egypt; \\ nouran_111ahmed@yahoo.com (N.A.A.A.E.-H.); aleim_77@yahoo.com (A.I.E.); \\ prof.sayedelsaadany@gmail.com (S.S.E.-s.) \\ 2 Department of Agricultural Sciences, University of Sassari, 07100 Sassari, Italy; pdeli@uniss.it \\ 3 Department of Crop, Food and Environmental Sciences, Marche Polytechnic University, 60131 Ancona, Italy \\ * Correspondence: 1.ledda@univpm.it
}

check for

updates

Citation: El-Hady, N.A.A.A.; ElSayed, A.I.; El-saadany, S.S.; Deligios, P.A.; Ledda, L. Exogenous Application of Foliar Salicylic Acid and Propolis Enhances Antioxidant Defenses and Growth Parameters in Tomato Plants. Plants 2021, 10, 74. https://doi.org/ 10.3390/plants10010074

Received: 1 December 2020 Accepted: 28 December 2020 Published: 1 January 2021

Publisher's Note: MDPI stays neutral with regard to jurisdictional clai$\mathrm{ms}$ in published maps and institutional affiliations.

Copyright: (C) 2021 by the authors. Licensee MDPI, Basel, Switzerland. This article is an open access article distributed under the terms and conditions of the Creative Commons Attribution (CC BY) license (https:// creativecommons.org/licenses/by/ $4.0 /)$.

\begin{abstract}
Salicylic acid (SA) and propolis (PR) are known to regulate the physiological process and to have a relevant role in bioactive compounds content. Our experiment was designed to evaluate the effect of SA and PR application on the growth, yield, and quality parameters of tomato grown for the fresh market in field conditions in Egypt. We studied the effect of twelve treatments where SA $(0.50,1.00,1.50,2.00$, and $2.50 \mathrm{mM})$ and $\mathrm{PR}\left(1,2,10,20\right.$, and $100 \mathrm{mg}$ propolis $\left.\mathrm{mL}^{-1}\right)$ were applied at increasing doses as a sole agent or combined each other $\left(1.50 \mathrm{mM}+10 \mathrm{mg} \mathrm{mL}^{-1}\right.$ for SA and PR, respectively). An untreated control was also considered. Tomato plants treated with SA (0.50, 1.00 , and $1.50 \mathrm{mM})$ showed a significant effect in all traits especially SA1 $(0.50 \mathrm{mM})$ in growth parameters and SA2 $(1.00 \mathrm{mM})$ in pigment and antioxidant content. Propolis foliar application was more effective than SA as it revealed that raising the concentration of aqueous extract enhanced the growth parameters and pigment in tomato. The best result was obtained by the $10 \mathrm{mg} \mathrm{mL}^{-1}$ treatment. The effect of propolis on antioxidant enzymes varied as the $10 \mathrm{mg} \mathrm{mL}^{-1}$ treatment was effective on peroxidases and superoxide dismutase, while $100 \mathrm{mg} \mathrm{mL}^{-1}$ was more effective on catalase. Salicylic acid and propolis have a positive effect on both preserving tomato plants and on nutrient supply, so the mixed intermediate concentration $\left(1.50 \mathrm{mM}+10 \mathrm{mg} \mathrm{mL}^{-1}\right)$ is considered very effective and results in an improvement of all plant traits.
\end{abstract}

Keywords: Solanum lycopersicum; agronomic traits; fruit yield; flavonoids; chlorophyll content; antioxidant enzyme activity

\section{Introduction}

Tomato (Solanum lycopersicum L.) is considered one of the most significant vegetable crops around the world. In 2017, about 182 million tons of tomatoes were harvested in the world. Furthermore, Egypt ranked as the fifth largest producer with a cultivated area of 182,444 ha and productivity of $40 \mathrm{t} \mathrm{ha}^{-1}$ [1], far lower as compared to the yield achieved in developed countries. Tomato fruits are characterized by a great number of high health-promoting bioactive compounds such as phenolic, carotenoids, vitamins, and glycoalkaloids [2]. Being of tropical origin, the plant species is well adapted to almost all climatic regions; however, the abiotic stresses are the main constraints of potential yield and quality of the tomato [3]. Environmental temperatures are rising due to the current global climate change, threatening the agricultural output [4]. High temperature causes different changes in plants such as physiological, morphological, biochemical, which influence their growth and development [5-7]. This leads to a reduction in yields of crop species, and therefore has a great effect on global food production [8]. Tomato plants grown under arid 
and semi-arid environment conditions are exposed to high temperature; this results in a reduced yield in many Solanum lycopersicum cultivars $[9,10]$. In this context, it is strategic to adopt some new methods to increase tomato production and improve the growth in an increasing temperatures scenario [11]. In several harsh environmental conditions such as drought, salt stress, and high temperature, plants endogenous antioxidant networks are not sufficient to protect [12]. Eventually, several reports have highlighted that cultural practices (e.g., appropriate nutrient solution concentration or use of exogenous adjuvants such as plant extracts) might improve the antioxidant composition of fruits or increase plants tolerance to stress due to different factors including salinity, high temperature, and diseases [13,14]. Propolis (PR) is considered a complex mixture consisting of compounds released by bees and derived from plants; therefore, its chemical composition varies due to the geographical and vegetal origins of these resins, as well as bee species $[15,16]$. Therefore, many studies reported the antimicrobial and antibiotic activities of bee propolis [17-19]. Salicylic acid (SA) is a natural growth regulator of vascular plants that impacts different physiological and metabolic processes, e.g., photosynthesis, transpiration, ion uptake, and transportation [20]. Exogenous application of salicylic acid increased the yield of vegetable species by reducing stress-induced growth reduction [21]. It was reported that the growthpromoting effects of SA may be related to changes in the hormonal status $[22,23]$ or by enhancing of photosynthesis, transpiration, and stomatal conductance [23,24], as well as antioxidant enzyme activities and osmoregulation [25]. The ameliorative effects of SA on tomato plants have been well-documented inducing salt, drought, and low temperature tolerance [26-28]. To the best of our knowledge, there are no studies that have discussed the effect of propolis and SA together on tomato. Therefore, the purpose of this study was to assess the protective effect of PR and SA on Solanum lycopersicum and yield attributes, physio-biochemical attributes, and antioxidant defense system components under natural environmental conditions (i.e., normal climate change conditions).

\section{Results}

\subsection{Morphological Characterization and Yield}

Treatments significantly affected agronomic and morphological characteristics of the crop (Table 1) with respect to the untreated control. The treatment of salicylic acid mixed with propolis showed the highest value for all traits, except for the number of flower cluster and leaf area, as the highest values were observed for PR5 and SA4, respectively. A steadily increasing effect of the propolis treatments has been observed in all traits by applying increasing concentrations. Accordingly, propolis supplied as solely agent at the highest concentration, namely, $100 \mathrm{mg} \mathrm{g}^{-1}$ (PR5), proved to be the second most effective treatment (after SA+PR), especially affecting length, height, and number of branches. An opposite trend was recorded for salicylic acid treatments, where we observed a systematically decreased effect by increasing its concentration (Table 1). Summarizing, compared with control (untreated plants), propolis and salicylic acid treatments showed significant variation in plant phenotypic (length, height, branch number, leaf number, flower cluster, and leaf area). Specifically, as the concentration of propolis used in the treatments increased, significant variations were observed for most of the phenotypic traits taken into account, namely, a greater height of the plant, a greater number of flower cluster, and a wider leaf area. By contrast, salicylic acid showed an opposite effect with respect to the increase of tested concentrations. Indeed, treatment SA5 (salicylic acid concentration $2.50 \mathrm{mM}$ ) showed a number of leaves and flower clusters per plant, and also a leaf area lower than the untreated control. 
Table 1. Effect of treatments on the main morphological and agronomic parameters of tomato during the 2018-2019 growing season.

\begin{tabular}{|c|c|c|c|c|c|c|}
\hline Treatments & $\begin{array}{l}\text { Length } \\
\text { (cm) }\end{array}$ & $\begin{array}{l}\text { Height } \\
\text { (cm) }\end{array}$ & $\begin{array}{c}\text { Branch } \\
\text { (no. } \text { plant }^{-1} \text { ) }\end{array}$ & $\begin{array}{c}\text { Leaf } \\
\text { (no. } \text { plant }^{-1} \text { ) }\end{array}$ & $\begin{array}{l}\text { Flower Cluster } \\
\text { (no. plant }^{-1} \text { ) }\end{array}$ & $\begin{array}{c}\text { Leaf Area } \\
\left(\mathrm{cm}^{2} \text { plant }^{-1}\right)\end{array}$ \\
\hline $\mathrm{SA}^{+}$ & $90.0 \mathrm{~cd}$ & $87.7 \mathrm{~cd}$ & $8.0 \mathrm{ab}$ & $55.3 \mathrm{ab}$ & 10.0 cdef & $753.6 \mathrm{cde}$ \\
\hline SA2 & $88.3 \mathrm{de}$ & $85.7 \mathrm{~d}$ & $7.0 \mathrm{abc}$ & $49.3 \mathrm{abcd}$ & 9.7 cdef & $942.0 \mathrm{cde}$ \\
\hline SA3 & $84.3 \mathrm{de}$ & $79.7 \mathrm{de}$ & $7.0 \mathrm{abc}$ & 47.0 cde & $8.6 \mathrm{def}$ & $1413 \mathrm{abc}$ \\
\hline SA4 & $80.0 \mathrm{de}$ & $78.3 \mathrm{de}$ & $5.3 \mathrm{bcd}$ & 39.7 efg & 8.0 ef & $2025 \mathrm{a}$ \\
\hline SA5 & $78.0 \mathrm{e}$ & $73.3 \mathrm{e}$ & $5.0 \mathrm{~cd}$ & $33.7 \mathrm{~g}$ & $7.0 \mathrm{f}$ & $134.3 \mathrm{e}$ \\
\hline PR1 $\ddagger$ & $90.0 \mathrm{~cd}$ & $86.3 \mathrm{~d}$ & $7.0 \mathrm{abc}$ & $35.0 \mathrm{fg}$ & 11.6 bcde & 1077 bcd \\
\hline PR2 & 99.7 bc & $96.0 \mathrm{bc}$ & $7.0 \mathrm{abc}$ & 45.6 cde & $12.3 \mathrm{bcd}$ & 1119 bcd \\
\hline PR3 & $102.3 \mathrm{~b}$ & $97.3 \mathrm{~b}$ & $7.3 \mathrm{abc}$ & 46.6 cde & $13.6 \mathrm{abc}$ & $1830 \mathrm{ab}$ \\
\hline PR4 & $102.7 \mathrm{~b}$ & $99.0 \mathrm{~b}$ & $7.7 \mathrm{abc}$ & 47.3 bcde & $15.3 \mathrm{ab}$ & 752.3 cde \\
\hline PR5 & $104.7 \mathrm{~b}$ & $100.6 \mathrm{~b}$ & $8.3 \mathrm{a}$ & $52.3 \mathrm{abc}$ & $17.0 \mathrm{a}$ & $1123 \mathrm{bcd}$ \\
\hline $\mathrm{SA}+\mathrm{PR} \S$ & $116.3 \mathrm{a}$ & $113.6 \mathrm{a}$ & $8.7 \mathrm{a}$ & $56.0 \mathrm{a}$ & $15.3 \mathrm{ab}$ & $1178 \mathrm{bcd}$ \\
\hline Control & $53.3 \mathrm{f}$ & $48.3 \mathrm{f}$ & $3.7 \mathrm{~d}$ & 42.6 def & 9.0 def & 434.8 de \\
\hline
\end{tabular}

Mean values in each column followed with different letters indicate significant differences at $p<0.05$ level. ${ }^{\dagger}$ SA1-SA5: salicylic acid treatment at $0.50,1.00,1.50,2.00$, and $2.50 \mathrm{mM}$, respectively. $\ddagger$ PR1-PR5: propolis treatment at 1, 2, 10, 20, and 100 mg propolis $\mathrm{mL}^{-1}$ concentration, respectively. ${ }^{\S} \mathrm{SA}+\mathrm{PR}: 1.50 \mathrm{mM}+10 \mathrm{mg} \mathrm{mL}^{-1}$ for salicylic acid and propolis, respectively.

The number and the weight of fruits were significantly $(p<0.05)$ influenced by treatments (Table 2), and foliar application of propolis was more effective than salicylic acid. Indeed, the PR5 treatment provided the highest fruits number with 18 fruit plant ${ }^{-1}$, followed by PR4 and SA1. The lowest number of fruit was obtained in the SA5 treatment. The fruit weight was significantly higher in SA1, SA2, and PR5. The highest fruit yield (Table 2) was recorded for the SA+PR treatment with $6.7 \mathrm{~kg} \mathrm{FW} \mathrm{m}^{-2}$. Propolis confirmed to be more effective than SA, as the application of PR5 produced $2.5 \mathrm{~kg} \mathrm{FW} \mathrm{m}^{-2}$ for early yield and $6.3 \mathrm{~kg} \mathrm{FW} \mathrm{m}^{-2}$ for total yield.

Table 2. Effect of treatments on the yield parameters of tomato plants during the 2018-2019 growing season.

\begin{tabular}{|c|c|c|c|c|}
\hline Treatments & $\begin{array}{c}\text { Fruit } \\
{\text { (no. } \text { plant }^{-1} \text { ) }}^{\text {nat }}\end{array}$ & $\begin{array}{l}\text { Fruit Weight } \\
\quad\left(\text { g unit }^{-1} \text { ) }\right.\end{array}$ & $\begin{array}{c}\text { Early Yield } \\
\left(\mathrm{kg} \mathrm{FW} \mathrm{m}^{-2}\right)\end{array}$ & $\begin{array}{c}\text { Total Yield } \\
\left(\mathrm{kg} \mathrm{FW} \mathrm{m}^{-2}\right)\end{array}$ \\
\hline $\mathrm{SA}^{+}$ & $15.7 \mathrm{abc}$ & $95.5 \mathrm{a}$ & 1.3 cde & $5.2 \mathrm{bc}$ \\
\hline SA2 & $14.0 \mathrm{bcd}$ & $95.3 \mathrm{a}$ & $1.2 \mathrm{de}$ & 5.0 bcde \\
\hline SA3 & $13.7 \mathrm{bcd}$ & $82.8 \mathrm{~d}$ & $1.0 \mathrm{e}$ & 4.8 cdef \\
\hline SA4 & $12.3 \mathrm{~cd}$ & $80.2 \mathrm{~d}$ & $1.0 \mathrm{e}$ & 4.1 ef \\
\hline SA5 & $12.0 \mathrm{~d}$ & $72.3 \mathrm{e}$ & $0.9 \mathrm{e}$ & $4.0 \mathrm{f}$ \\
\hline PR1 $\ddagger$ & $13.3 \mathrm{bcd}$ & $73.0 \mathrm{e}$ & $1.7 \mathrm{bcd}$ & $4.3 \mathrm{cdef}$ \\
\hline PR2 & $14.0 \mathrm{bcd}$ & $80.7 \mathrm{~d}$ & $1.8 \mathrm{bc}$ & 5.0 bcde \\
\hline PR3 & $15.7 \mathrm{abc}$ & $83.7 \mathrm{~d}$ & $2.1 \mathrm{ab}$ & $5.1 \mathrm{bcd}$ \\
\hline PR4 & $16.7 \mathrm{ab}$ & $88.0 \mathrm{c}$ & $2.2 \mathrm{ab}$ & $5.8 \mathrm{ab}$ \\
\hline PR5 & $18.0 \mathrm{a}$ & $93.3 \mathrm{ab}$ & $2.5 \mathrm{a}$ & $6.3 \mathrm{a}$ \\
\hline $\mathrm{SA}+\mathrm{PR} \S$ & $16.0 \mathrm{ab}$ & $91.3 \mathrm{bc}$ & $2.6 \mathrm{a}$ & $6.7 \mathrm{a}$ \\
\hline Control & $11.0 \mathrm{~d}$ & $66.2 \mathrm{f}$ & $1.0 \mathrm{e}$ & $4.2 \mathrm{def}$ \\
\hline
\end{tabular}

Mean values in each column followed with different letters indicate significant differences at $p<0.05$ level. ${ }^{+}$SA1-SA5: salicylic acid

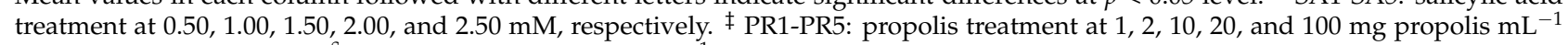
concentration, respectively. ${ }^{\S} \mathrm{SA}+\mathrm{PR}: 1.50 \mathrm{mM}+10 \mathrm{mg} \mathrm{mL}^{-1}$ for salicylic acid and propolis, respectively.

\subsection{Biochemical Compounds Content}

The maximum total soluble solids (TSS) was recorded in SA+PR and the lowest amount in SA5 (Table 3). A progressive increase in the total flavonoids and phenolic content was observed at higher concentrations of salicylic acid and propolis. The highest level of total flavonoid and total phenolic was recorded in PR5 treatment. The highest effect on protein content was recorded in SA5 followed by PR5. 
Table 3. Effect of treatments on the biochemical changes of tomato plant leaves during the 2018-2019 growing season.

\begin{tabular}{|c|c|c|c|c|c|}
\hline Treatments & $\begin{array}{c}\text { Total Soluble Solids } \\
(\%)\end{array}$ & $\begin{array}{c}\text { Total Flavonoids } \\
\left(\mathrm{mg} \mathrm{g}^{-1} \mathrm{FW}\right)\end{array}$ & $\begin{array}{l}\text { Total Phenolic } \\
\left(\mathrm{mg} \mathrm{g}^{-1} \mathrm{FW}\right)\end{array}$ & $\begin{array}{l}\text { Protein Content } \\
\left(\mathrm{mg} \mathrm{g}^{-1} \mathrm{FW}\right)\end{array}$ & $\begin{array}{c}\text { Proline } \\
\left(\mathrm{mg} \mathrm{g}^{-1} \mathrm{FW}\right)\end{array}$ \\
\hline $\mathrm{SA}^{\dagger}$ & $4.63 \mathrm{c}$ & $130.80 \mathrm{k}$ & $136.73 \mathrm{j}$ & $43.55 \mathrm{e}$ & $0.107 \mathrm{k}$ \\
\hline SA2 & $4.66 \mathrm{bc}$ & $169.76 \mathrm{j}$ & $142.03 \mathrm{i}$ & $46.10 \mathrm{de}$ & $0.114 \mathrm{i}$ \\
\hline SA3 & $4.57 \mathrm{c}$ & $213.40 \mathrm{~h}$ & $154.90 \mathrm{~h}$ & 51.45 bcde & $0.117 \mathrm{~h}$ \\
\hline SA4 & $4.33 \mathrm{~d}$ & $221.00 \mathrm{f}$ & $155.23 \mathrm{~g}$ & $57.95 \mathrm{bc}$ & $0.319 \mathrm{~d}$ \\
\hline SA5 & $3.90 \mathrm{f}$ & $222.60 \mathrm{~d}$ & $161.26 \mathrm{~d}$ & $74.75 \mathrm{a}$ & $0.649 \mathrm{a}$ \\
\hline PR1 $\ddagger$ & $3.30 \mathrm{~g}$ & $211.10 \mathrm{i}$ & $159.60 \mathrm{f}$ & 47.45 cde & $0.111 \mathrm{j}$ \\
\hline PR2 & $4.13 \mathrm{e}$ & $221.00 \mathrm{f}$ & $160.06 \mathrm{e}$ & 49.90 bcde & $0.111 \mathrm{j}$ \\
\hline PR3 & $4.60 \mathrm{c}$ & $221.80 \mathrm{e}$ & $167.46 \mathrm{c}$ & 54.75 bcde & $0.141 \mathrm{f}$ \\
\hline PR4 & $4.80 \mathrm{~b}$ & $222.80 \mathrm{c}$ & $174.80 \mathrm{~b}$ & $56.95 \mathrm{bcd}$ & $0.145 \mathrm{e}$ \\
\hline PR5 & $5.20 \mathrm{a}$ & $225.90 \mathrm{a}$ & $193.20 \mathrm{a}$ & $60.20 \mathrm{~b}$ & $0.394 \mathrm{c}$ \\
\hline $\mathrm{SA}+\mathrm{PR} \S$ & $5.27 \mathrm{a}$ & $223.76 \mathrm{~b}$ & $131.63 \mathrm{k}$ & 50.95 bcde & $0.516 \mathrm{~b}$ \\
\hline Control & $4.33 \mathrm{~d}$ & $220.03 \mathrm{~g}$ & 128.731 & 48.95 bcde & $0.127 \mathrm{~g}$ \\
\hline
\end{tabular}

Mean values in each column followed with different letters indicate significant differences at $p<0.05$ level. ${ }^{\dagger}$ SA1-SA5: salicylic acid

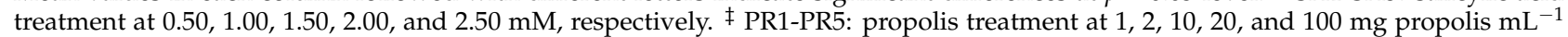
concentration, respectively. ${ }^{\S} \mathrm{SA}+\mathrm{PR}: 1.50 \mathrm{mM}+10 \mathrm{mg} \mathrm{mL}^{-1}$ for salicylic acid and propolis, respectively.

\subsection{Antioxidant Enzyme Activity}

In the range of SA1-SA4, the maximum activity of SOD and POD was observed (Figure 1a,b). Propolis had the greatest antioxidant enzymes activity at PR3 (for POD), even if significantly lower than SA2 and SA1 (Figure 1b). The PR5 treatment and mixed concentration were the most effective in affecting CAT enzyme amount (Figure 1c).

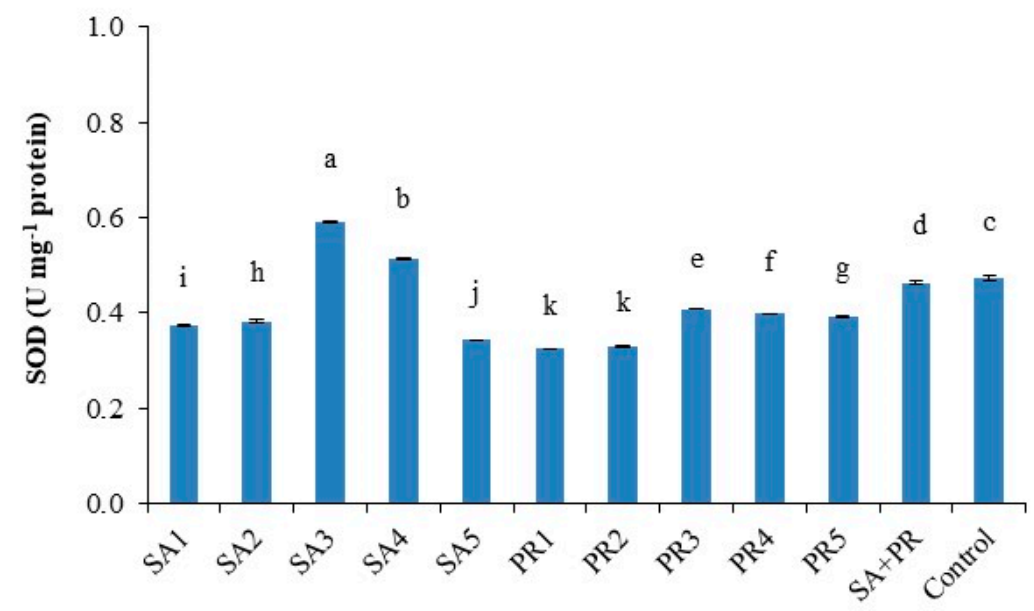

(a)

Figure 1. Cont. 


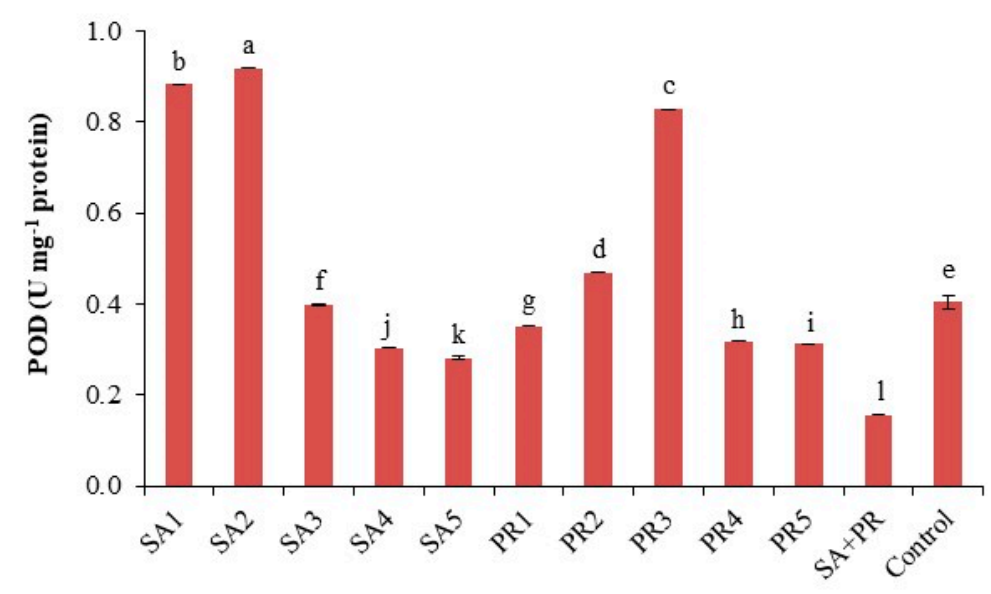

(b)

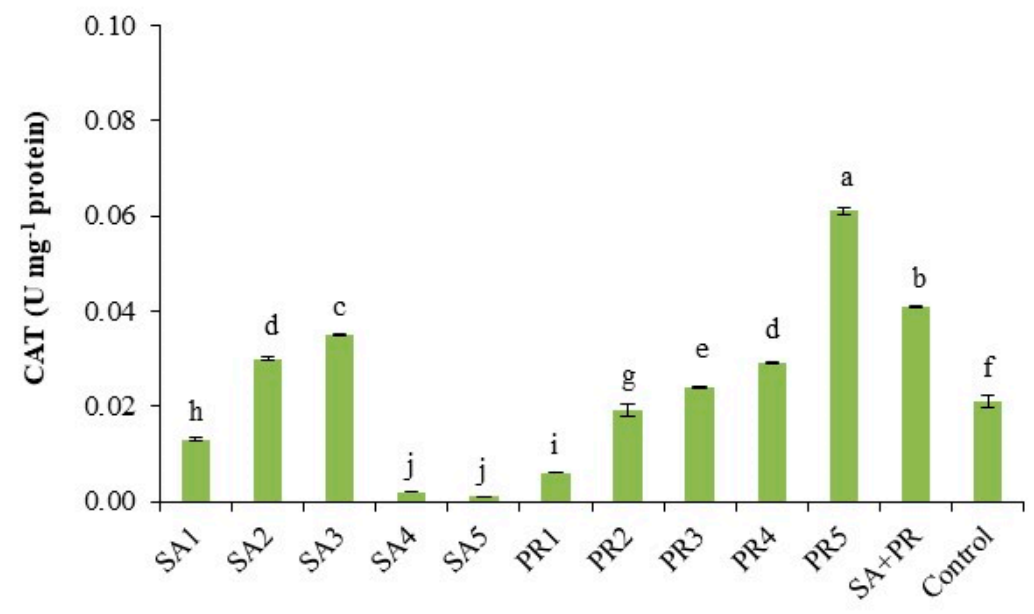

(c)

Figure 1. Antioxidant enzyme activities in tomato after treatments. (a) Superoxide dismutase, SOD ( $\mathrm{U} \mathrm{mg}^{-1}$ protein); (b) peroxidases, POD ( $\mathrm{U} \mathrm{mg}^{-1}$ protein); (c) catalase CAT ( $\mathrm{U} \mathrm{mg}^{-1}$ protein). The data presented are the mean of three replicates. Significant differences $(p<0.05)$ among the treatments are indicated by different letters, \pm bars indicate standard errors of the mean.

\subsection{Chlorophyll and Carotenoid Content}

Application of high concentration of propolis and the mixed treatment $\mathrm{SA}+\mathrm{PR}$ caused a significant increase in chlorophyll $a$, chlorophyll $b$, and carotenoids (Figure 2). In particular, propolis at the highest concentration determined the maximum chlorophyll $a$ (Figure 2a) and carotenoids content (Figure 2c). The control was highest in chlorophyll $b$ content, significantly different from SA2 and PR5 (Figure 2b). 


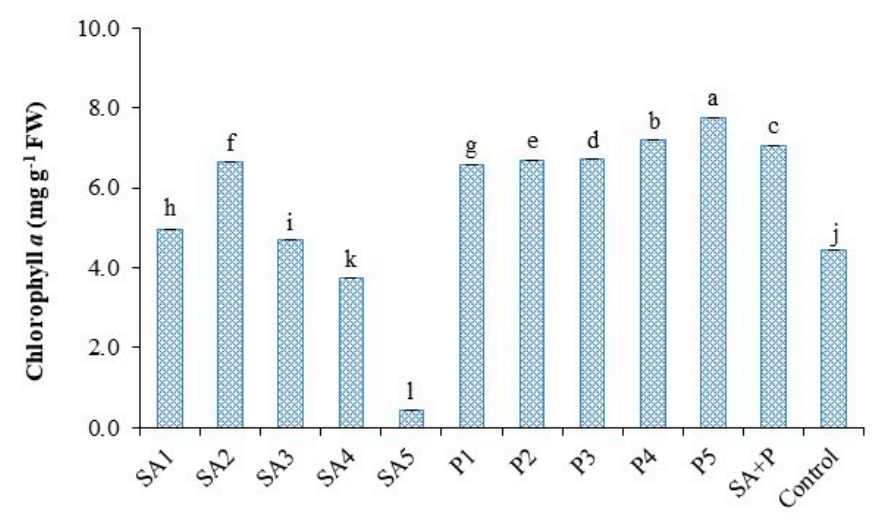

(a)

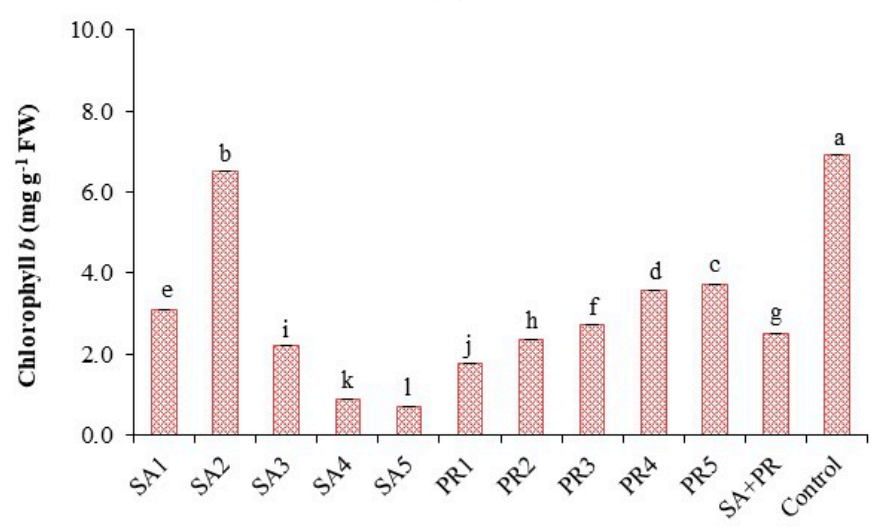

(b)

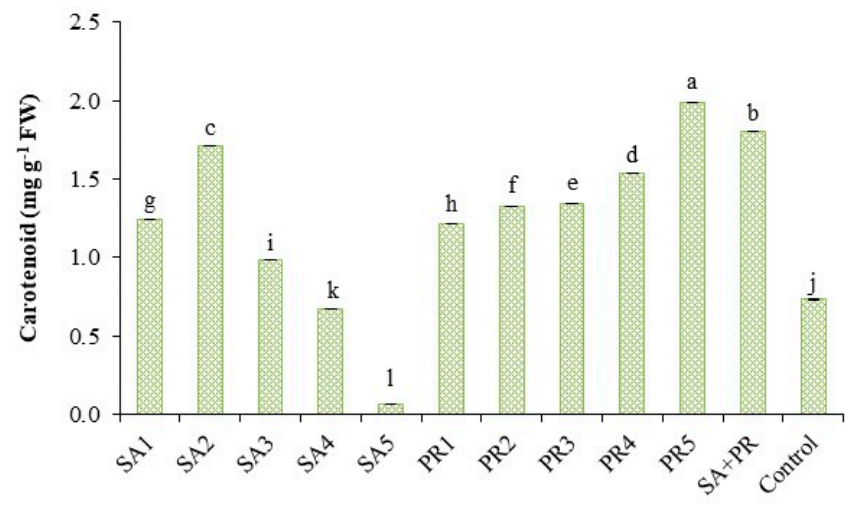

(c)

Figure 2. Effect of different concentrations of salicylic acid (SA) and propolis (PR) on (a) chlorophyll $a$; (b) chlorophyll $b$; and (c) carotenoid content in tomato $\left(\mathrm{mg} \mathrm{g}^{-1} \mathrm{FW}\right)$. The data presented are the mean of three replicates. Significant differences $(p<0.05)$ among the treatments are indicated by different letters; where visible, \pm bars indicate standard errors of the mean.

\section{Discussion}

\subsection{Morphological Characterization and Yield}

Salicylic acid had a stimulation effect on growth characters of tomato plants and this effect increased by increasing salicylic acid concentration in the range $0.50-2.50 \mathrm{mM}$ as also reported by Yildrim and Dursun [29] who found highest tomato yield at $0.50 \mathrm{mM}$ salicylic acid foliar treatment. Moreover, our results are confirmed by Gharib [30] that investigating the application of SA at low concentration observed a higher photosynthetic activity, which enhanced plant height, number of branches and leaves, as well as leaf area, fresh and dry weight. Our study clarified the enhancing and stimulatory effect of the aqueous extract of 
propolis as foliar spray on tomato plants. The increase in vegetative growth that we have observed was probably due to its high level of biochemical compounds [31,32]. Indeed, the propolis contains large amounts of antioxidants owing to the extent of flavonoids and other effective compounds that prevent the oxidation and damage of the plant [33] and lead to organize plant growth [34]. Additionally, the effectiveness of propolis may also be related to the extraction method; as Santos [35] reported, the aqueous extract had the highest antioxidant activity because of its highest content of phenolic compounds. In this study, the use of high concentrations of propolis and low concentrations of salicylic acid, or the combination of the two agents ( $\mathrm{SA}+\mathrm{PR}$ treatment), provided the highest yields. The increase of fresh weight that we observed in Table 2 may be due to the promoted availability of micro- and macro-nutrients [36,37]. In our experiment, propolis and salicylic acid have been proved to have a vital role in fasten maturity in tomato plants, and these results are confirmed by other studies $[8,29]$. Specifically, for propolis, it was argued that it does not increase the early yield directly, but preserves the fruits by forming a protective layer against different types of microbes, especially fungi that affect the fruits of tomatoes greatly and lead to a high loss of young fruits [38,39].

The increasing values of growth parameters of plants treated with propolis could also be attributed to the rise in indoles in these plants that might stimulate an increase in cell division and enlargement [40,41], beside the highest amount of terpenoids that enhance the plant metabolism [42], as well as fresh and dry weight [43,44].

\subsection{Biochemical Compounds Content}

In agreement with our findings, other studies reported that the amount of acidity, TSS, and soluble protein were influenced by SA treatment $[45,46]$. The explanation is probably due to the fact that SA induces the production of hydrogen peroxide, which stimulates a great activity of phenylalanine ammoniumlyase, responsible for the synthesis of phenolic compounds [47]. The SA plays a vital role in increasing the synthesis of phytochemical compounds and antioxidants as well as activates the secondary metabolism, as reported by Mora-Herrera et al. [48]. Salicylic acid possibly improved protein content by the induction of protein kinase synthesis $[18,41,49]$ whereas through regulation of proline synthesis led to increase the plant defense system and activate adaptive responses. Propolis treatments significantly increased total protein and proline content as observed in Table 3 compared with the control plants as also recorded by El-Yazal working on spinach [50].

\subsection{Antioxidant Enzyme Activity}

SOD, POD, and CAT enzymes protect plants' cellular activity and they modify scavenger enzymes expression in the cell membrane system against oxidative damage [51,52]. Our findings are confirmed by results of other studies carried out on different species [53,54]. In our study, a significant increase of SOD and POD was observed by SA applications. This was similar to the observed increase in antioxidant enzymes activity in tomato plants recorded by Hayat et al. [55]. According to the propolis, there was not any previous study that indicated the role of foliar application on POD, SOD, and CAT antioxidant enzymes. Our results in Figure 1 showed a significant effect on the concentration of antioxidant enzymes because of foliar application of propolis. This is because propolis is considered natural material rich in bioactive compounds such as polyphenolic compounds, flavones, flavonones, as well as phenolic and antioxidant enzymes [56]. Total polyphenol and flavonoid contents are investigated to be the most effective antioxidant in propolis [57].

\subsection{Chlorophyll and Carotenoid Content}

Leaf pigments concentration (chlorophyll $a$, chlorophyll $b$, and total carotenoids) raised by applying propolis extract as a foliar treatment was also found by other studies [58]. The increment of leaf pigments concentration of propolis treatments might be attributed to the rise in their treatments hormones and enhances mineral absorption, i.e., ( $\mathrm{Fe}$ and $\mathrm{Me}$ ), which are required for chlorophyll synthesis $[59,60]$. The mixed concentration of $(\mathrm{SA}+\mathrm{PR})$ showed 
the most significant value in most traits. This is due to the effect of two intermediate concentrations of two bioactive substances, one of which positively affects growth factors and the other affects the content of biochemical and photosynthesis of plants. This may be regarded as the first result of its kind, which proves the effectiveness of two natural vital substances, one of them from a botanical source and the other from the secondary products of bees.

\section{Materials and Methods}

\subsection{Experimental Conditions}

The field trial was conducted in the new Salhia in Sharkia governorate $\left(72^{\circ} 32^{\prime} \mathrm{E} ; 23^{\circ} 3^{\prime}\right.$ $\mathrm{N})$, Egypt, during the October 2018-2019 growing season. The soil of the area is clay-loam with $8.1 \mathrm{pH}, 0.92 \%$ soil organic matter content, and $0.01 \% \mathrm{~N}$. In this location, usually June is a rainless month, whereas most rainfall occurs in December (average monthly rainfall: $7 \mathrm{~mm}$ ). Yearly, the hottest month is August (average monthly temperature: $26.8^{\circ} \mathrm{C}$ ) [61] (Figure 3).

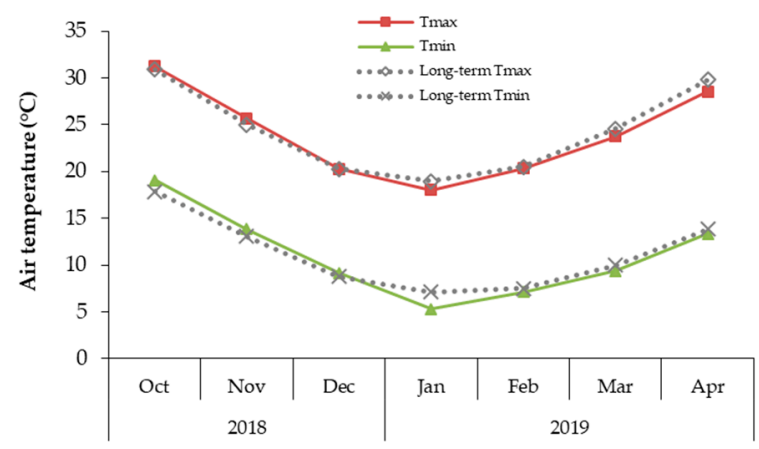

(a)

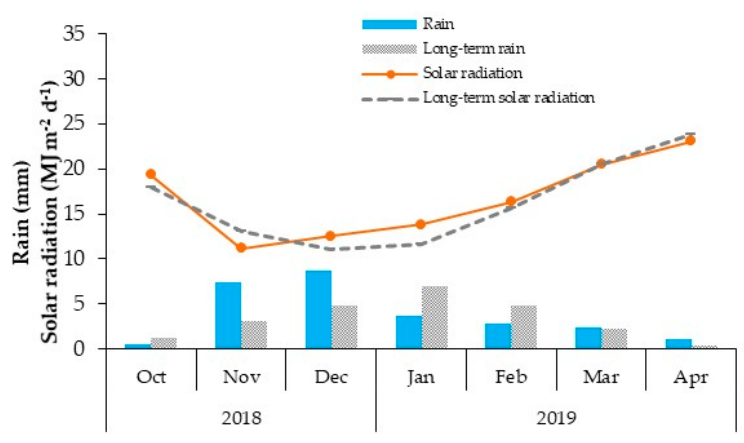

(b)

Figure 3. Seasonal time series for (a) air temperatures $\left({ }^{\circ} \mathrm{C}\right)$; and $(\mathbf{b})$ rain $(\mathrm{mm})$ and solar radiation $\left(\mathrm{MJ} \mathrm{m}^{-2} \mathrm{~d}^{-1}\right)$ over the Sharkia governorate region (1989-2012) and comparison with the weather trend occurred during the 2018-2019 growing season.

\subsection{Plant Material and Experimental Design}

To improve physical and chemical properties of tomato plants, two different stimulants were tested sole or in combination: salicylic acid (SA; 2-hydroxybenzoic acid; Sigma Chemical Co., Gillingham, UK) and propolis (as an organic biostimulant) (taken from the apiary of Beekeeping Research Section, Plant Protection Research Institute, Agriculture Research Centre at Dokki, Giza, Egypt). The chemical description of the propolis used in this study is presented in Table 4. A total of twelve treatments were tested. The tomato hybrid Al-Quds E448 (Ministry of Agriculture-Tadress Lyon Company, Cairo, Egypt) was considered for the experiment. The experiment was organized in a completely randomized block design with three replications. Each experimental unit size was $20 \mathrm{~m}^{2}$ with five rows (150 plants per plot), $9 \mathrm{~m}$ in length, and 50-wide row spacing. 
Table 4. Chemical description of the Egyptian propolis (honey bee species Apis mellifera lamarckii).

\begin{tabular}{cc}
\hline Parameter & Value \\
\hline Moisture (\%) & 7.05 \\
Proteins (\%) & 11.03 \\
Fats (\%) & 23.12 \\
Fibers (\%) & 51.02 \\
Carbohydrates (\%) & 6.02 \\
Ash (\%) & 2.11 \\
Resin (\%) & 57.92 \\
Insoluble matter (\%) & 40.91 \\
Volatile substances (\%) & 3.33 \\
Total phenolic content (mg GAE g ${ }^{-1}$ sample DW) & 253.70 \\
Total flavonoid content (mg quercetin $\mathrm{g}^{-1}$ sample DW) & 76.77 \\
Total alkaloid (g 100 g ${ }^{-1} \mathrm{FW}^{2}$ & 5.42 \\
\hline
\end{tabular}

\subsection{Field Management and Treatment Description}

The tomato seedlings were transplanted on 10 October 2018, and whole seedling samples were taken before the experiment began. During the experiment, $100 \mathrm{~g}$ natural organic fertilizer (Cow manure, Hebei Shuanglian Biological Technology Co., Hebei, China), $100 \mathrm{~g}$ chicken manure compost (Hebei Shuanglian Biological Technology Co., Hebei, China), $1000 \mathrm{~g}$ agricultural sulfur (Agriculture soreil, Kafr El Zayat Pesticides and Chemicals Co., Kafr El Zayat, Egypt), $500 \mathrm{~g}$ of N (Ammonia sulphate, SEMADCO Co., Suez, Egypt), $75 \mathrm{~g}$ of $\mathrm{P}_{2} \mathrm{O}_{5}$ (Superphosphate, Suez Company For Fertilizer Production, Suez, Egypt), and $500 \mathrm{~g}$ of $\mathrm{K}_{2} \mathrm{O}$ (Potassium sulphate, Suez Company For Fertilizer Production, Suez, Egypt) were supplied by fertigation. No insecticides and fungicides were used during the experiment. Weeds were controlled manually. Salicylic acid was initially dissolved in $100 \mu \mathrm{L}$ dimethyl sulfoxide and concentrations of 0.50 (SA1 treatment), 1.00 (SA2 treatment), 1.50 (SA3 treatment), 2.00 (SA4 treatment), and $2.50 \mathrm{mM}$ (SA5 treatment) at $\mathrm{pH} 6.0-6.5$; the solutions were completed with distilled water containing $0.02 \%$ Tween 20 (Polyoxyethylenesorbitan monolaurate, Sigma Chemicals, Gillingham, UK) [62]. The first SA treatment occurred after 20 days when the young plants had 2-3 true leaves. Leaves, both in the lower and upper surfaces [63], were sprayed with the SA solutions until dripping with a held atomizer. Before utilization, $50 \mathrm{~g}$ of propolis was freeze-dried for three hours, suspended and extracted with $50 \mathrm{~mL}$ of ethanol (70\%), and kept on a shaker at $150 \mathrm{rpm}$ for two days at $26^{\circ} \mathrm{C}$. Then, the extract was centrifuged at $28,000 \times g$ for $30 \mathrm{~min}$, and the supernatant was collected and evaporated at room temperature $\left(25^{\circ} \mathrm{C}\right)$ for 3 days; thus, the remaining resin was collected for further testing [64]. Dilutions of 1:10, 1:50, 1:100, 1:500, and 1:1000 were prepared with the final concentrations of 1 (PR1 treatment), 2 (PR2 treatment), 10

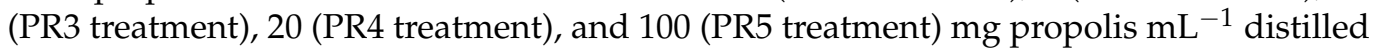
water, respectively, and then temporarily stored at room temperature. The initial foliar propolis treatment occurred after 20 days when the seedlings had 2-3 true leaves. The propolis was sprayed with the solutions until dripping with a held atomizer. Plants treated with water were used as untreated control (Control treatment). An additional treatment $(\mathrm{SA}+\mathrm{PR})$ mixing salicylic acid $(1.50 \mathrm{mM})$ with propolis $\left(10 \mathrm{mg}\right.$ propolis $\left.\mathrm{mL}^{-1}\right)$ was tested. Treatments were applied at a 15-day time interval, and after 10 days from the last treatment, vegetative samples were taken.

\subsection{Growth and Quality Monitoring and Analysis}

Sixty days after transplanting, four plants were harvested for each replication, and data on plant growth variables were collected (e.g., plant length and height; branches and leaves number; plant leaf area, the number of flower clusters and fruits, the unit fruit weight, early and total yield). The yield of the first three pickings ( $25 \%$ of pickings number) was calculated as the early yield. At the end of the crop cycle, the total production was calculated. Plant height was measured from the ground level to the apical meristem of the main stem and plant length from the roots to the apical meristem of the main stem 
carrying the longest leaf. Plant dry weight was mathematically obtained by summing leaf and stem dry weight; whereas the number of leaves per plant was determined by counting all leaves of the plant including new tips and sprouts. Leaf area per plant was calculated utilizing the leaf area-leaf weight relationship as described by Taha and Osman [65]. Leaf area per plant $\left(\mathrm{cm}^{2}\right)$ was obtained utilizing the formula in which the total leaf dry weight (g) is LDW, the disks dry weight $(\mathrm{g})$ is DDW, and the area of disks $\left(\mathrm{cm}^{2}\right)$ is DA:

$$
\text { Leaf area } / \text { plant }=\frac{\mathrm{LDW}}{\mathrm{DDW}} \times \mathrm{DA} .
$$

The total yield for each treatment was calculated by weighing the fruits picked in each replication and converting the weight into $\mathrm{kg}$ per $\mathrm{m}^{2}$. In addition, the average percentage of dry matter and total soluble solids (TSS \%) were determined as described in AOAC official methods [66] as indictors of fruit quality.

\subsection{Leaf Pigments}

Leaf pigments contents, namely, chlorophyll $a, b$ and carotenoid ( $\mathrm{mg} \mathrm{g}^{-1}$ fresh weight) were quantitatively determined and calculated as described by Lichtenthaler [67].

\subsection{Biochemical Measurements}

Total phenolic compounds (TPCs) were estimated ( $\mathrm{mg} \mathrm{g}^{-1} \mathrm{FW}$ ) by the Folin-Ciocalteu reagent as reported by Singleton et al. [68]. Total flavonoids (TFs) were established ( $\mathrm{mg} \mathrm{g}^{-1} \mathrm{FW}$ ) according to the protocol of Ordonez et al. [69]. For the quantitatively measurements of antioxidant enzymes activities, the samples of leaves were milled and turned into fine powder in liquid nitrogen and extracted with $10 \mathrm{~mL}$ of $50 \mathrm{mM}$ phosphate buffer, $\mathrm{pH}$ 7.0. The homogenate was centrifuged at $20,000 \times \mathrm{g}$ for $30 \mathrm{~min}$ at $4{ }^{\circ} \mathrm{C}$. In order to measure antioxidant enzyme activities, the supernatant was then filtered and used. Total soluble protein content was measured by utilizing the Bradford procedure [70]. Superoxide dismutase (SOD) activity assayed as reported in Giannopolitis and Ries [71]. Catalase (CAT) activity assayed as suggested by Aebi (1984) [72]. In tomato leaves, peroxidase (POD) activity was determined utilizing the procedure by Thomas et al. [73]. All solvents used in this work were obtained from different companies. Gallic acid, quercetin, DPPH; and substrates were purchased by Sigma Chemical Co., Gillingham, UK.

\subsection{Statistical Analysis}

Data presented as the mean of three independent determinations. One-way ANOVA was used to evaluate the impact of treatments on all parameters with the Duncan's multiple range test. The differences between the means were considered significant at $p \leq 0.05$. All analyses were performed using the SAS statistical software (SAS v. 9.2, SAS Institute, Cary, NC, USA).

\section{Conclusions}

The utilization of salicylic acid as a foliar application on tomato plants had a great effect as a growth regulator probably because takes part in the adjustment of plant physiological processes, especially when it is used at small concentrations from $0.50 \mathrm{mM}$ to $1.50 \mathrm{mM}$. On the other hand, propolis has not only increased the total plant performance, with regard to development and production, but it has also shown a relevant effect on the biochemistry of tomato plants especially in the effect on antioxidant enzymes. The mixed concentration of propolis and SA has been the most effective treatment to enhance tomato plants with physiological properties and nutrient elements and to adapt open field tomato cropping to climate change temperature trends. 
Author Contributions: Conceptualization, N.A.A.A.E.-H. and L.L.; methodology, N.A.A.A.E.-H. and A.I.E.; statistical analysis, P.A.D.; investigation and data curation, N.A.A.A.E.-H.; writingoriginal draft preparation, N.A.A.A.E.-H., A.I.E., and P.A.D.; writing-review and editing, A.I.E., S.S.E.-S., and L.L.; supervision, S.S.E.-s. All authors have read and agreed to the published version of the manuscript.

Funding: This research did not receive any specific grant from funding agencies in the public, commercial, or not-for-profit sectors.

Institutional Review Board Statement: Not applicable.

Informed Consent Statement: Not applicable.

Data Availability Statement: The data presented in this study are available on reasonable request from the corresponding author. The datasets generated and analyzed during the current study are not publicly available due to a further related paper that deals with ecotypes used in the experiment and the genotype $\times$ environment interaction.

Acknowledgments: N.A.A.A.E.-H. acknowledges the University of Zagazig and the European Union (EU).

Conflicts of Interest: The authors declare no conflict of interest.

\section{References}

1. Food and Agriculture Organization (FAO). FAOSTAT. FAO Statistics Division. 2017. Available online: http://www.fao.org/ faostat/en/\#data/QC (accessed on 13 July 2020).

2. Chaudhary, P.; Sharma, A.; Singh, B.; Nagpal, A.K. Bioactivities of Phytochemicals Present in Tomato. J. Food Sci. Technol. 2018, 55, 2833-2849. [CrossRef]

3. Hagassou, D.; Francia, E.; Ronga, D.; Buti, M. Blossom End-Rot in Tomato (Solanum lycopersicum L.): A Multi-Disciplinary Overview of Inducing Factors and Control Strategies. Sci. Hortic. 2019, 249, 49-58. [CrossRef]

4. Sun, Q.; Miao, C.; Hanel, M.G.L.; Borthwick, A.; Duan, Q.; Ji, D.; Li, H. Global Heat Stress on Health, Wildfires, and Agricultural Crops under Different Levels of Climate Warming. Environ. Int. 2019, 128, 125-136. [CrossRef]

5. Mathur, S.; Agrawal, D.; Jajoo, A. Photosynthesis: Response to High Temperature Stress. J. Photochem. Photobiol. 2014, 137, 116-126. [CrossRef]

6. Ohama, N.; Sato, H.; Shinozaki, K.; Yamaguchi-Shinozaki, K. Transcriptional Regulatory Network of Plant Heat Stress Response. Trends Plant Sci. 2017, 22, 53-65. [CrossRef]

7. Deligios, P.A.; Chergia, A.P.; Sanna, G.; Solinas, S.; Todde, G.; Narvarte, L.; Ledda, L. Climate Change Adaptation and Water Saving by Innovative Irrigation Management Applied on Open Field Globe Artichoke. Sci. Total Environ. 2019, 649, 461-472. [CrossRef]

8. Shinwari, A.; Ahmad, I.; Khan, I.; Khattak, H.; Azimi, A.S. Thermo-Tolerance in Tomato: Acetyl Salicylic Acid Affects Growth and Yield of Tomato (Solanum lycopersicum L.) under the Agro-Climatic Condition of Islamabad, Pakistan. Adv. Agric. Environ. Sci. 2018, 1, 102-107. [CrossRef]

9. EL-Saka, I.Z. Tomato Breeding for Heat Stress Conditions. EJAE 2016, 3, 87-93.

10. Driedonks, N.; Wolters-Arts, M.; Huber, H.; de Boer, G.J.; Vriezen, W.; Mariani, C.; Rieu, I. Exploring the Natural Variation for Reproductive Thermotolerance in Wild Tomato Species. Euphytica 2018, 214, 67. [CrossRef]

11. Ruggieri, V.; Calafiore, R.; Schettini, C.; Rigano, M.M.; Olivieri, F.; Frusciante, L.; Barone, A. Exploiting Genetic and Genomic Resources to Enhance Heat-Tolerance in Tomatoes. Agronomy 2019, 9, 22. [CrossRef]

12. Rady, M.M.; Talaat, N.B.; Abdelhamid, M.T.; Shawky, B.T.; Desoky, E.M. Maize (Zea mays L.) Grains Extract Mitigates the Deleterious Effects of Salt Stress on Common Bean (Phaseolus vulgaris L.) Growth and Physiology. J. Hortic. Sci. Biotechol. 2019, 94, 777-789. [CrossRef]

13. Jahan, M.S.; Wang, Y.; Shu, S.; Zhong, M.; Chen, Z.; Wu, J.; Sun, J.; Guo, S. Exogenous Salicylic Acid Increases the Heat Tolerance in Tomato (Solanum lycopersicum L.) by Enhancing Photosynthesis Efficiency and Improving Antioxidant Defense System Through Scavenging of Reactive Oxygen Species. Sci. Hortic. 2019, 247, 421-429. [CrossRef]

14. Sabatino, L.; D'Anna, F.; Iapichino, G.; Moncada, A.; D’Anna, E.; De Pasquale, C. Interactive Effects of Genotype and Molybdenum Supply on Yield and Overall Fruit Quality of Tomato. Front. Plant. Sci. 2019, 9, 1922. [CrossRef]

15. El Sohaimy, S.; Masry, S. Phenolic Content, Antioxidant and Antimicrobial Activities of Egyptian and Chinese Propolis. Am. Eurasian J. Agric. Environ. Sci. 2014, 14, 1116-11124. [CrossRef]

16. Anjum, S.I.; Ullah, A.; Khan, K.A.; Attaullah, M.; Khan, H.; Ali, H.; Bashir, M.A.; Tahir, M.; Ansari, M.J.; Ghramh, H.A.; et al. Composition and Functional Properties of Propolis (Bee Glue): A Review. Saudi J. Biol. Sci. 2018, 26, 1695-1703. [CrossRef]

17. Debab, M.; Toumi-Benali, F.; Dif, M. Antioxidant Activity of Propolis of West Algeria. Phytothérapie 2016, 15, 230-234. [CrossRef]

18. Silva, R.P.D.; Machado, B.A.S.; DeAbreu Barreto, G.; Costa, S.S.; Andrade, L.N.; Amaral, R.G.; Carvalho, A.A.; Padilha, F.F.; Barbosa, J.D.V.; Umsza-Guez, M.A. Antioxidant, Antimicrobial, Antiparasitic, and Cytotoxic Properties of Various Brazilian Propolis Extracts. PLoS ONE 2017, 12, e017258. [CrossRef] 
19. Boufadi, Y.M.; Van Antwerpen, P.; Chikh Alard, I.; Nève, J.; Djennas, N.; Riazi, A.; Soubhye, J. Antioxidant Effects and Bioavailability Evaluation of Propolis Extract and Its Content of Pure Polyphenols. J. Food Biochem. 2018, 42, e12434. [CrossRef]

20. Ibrahim, A.; Abdel-Razzak, H.; Wahb-Allah, M.; Alenazi, M.; Alsadon, A.; Dewir, Y.H. Improvement in Growth, Yield, and Fruit Quality of Three Red Sweet Pepper Cultivars by Foliar Application of Humic and Salicylic Acids. HortTechnology 2019, 29, 170-178. [CrossRef]

21. Khan, M.I.; Fatma, M.; Per, T.S.; Anjum, N.A.; Khan, N.A. Salicylic Acid-Induced Abiotic Stress Tolerance and Underlying Mechanisms in Plants. Front. Plant. Sci. 2015, 6, 1-17. [CrossRef]

22. Shakirova, F.M.; Sakhabutdinova, A.R.; Bezrukova, M.V.; Fathkutdinova, R.A.; Fatkhutdinova, D.R. Changes in the Hormonal Status of Wheat Seedlings Induced by Salicylic Acid and Salinity. Plant. Sci. 2003, 164, 317-322. [CrossRef]

23. Abreu, M.E.; Munné-Bosch, S. Salicylic Acid Deficiency in NahG Transgenic Lines and sid2 Mutants Increases Seed Yield in the Annual Plant Arabidopsis thaliana. J. Exp. Bot. 2009, 60, 1261-1271. [CrossRef] [PubMed]

24. Stevens, J.; Senaratna, T.; Sivasithamparam, K. Salicylic Acid Induces Salinity Tolerance in Tomato (Lycopersicon esculentum cv. Roma): Associated Changes in Gas Exchange, Water Relations and Membrane Stabilisation. Plant Growth Regul. 2006, 49, 77-83. [CrossRef]

25. Faried, H.N.; Ayyub, C.M.; Amjad, M.; Ahmed, R.; Wattoo, F.M.; Butt, M.; Bashir, M.; Shaheen, M.R.; Waqas, M.A. Salicylic Acid Confers Salt Tolerance in Potato Plants by Improving Water Relations, Gaseous Exchange, Antioxidant Activities and Osmoregulation. J. Sci. Food Agric. 2017, 97, 1868-1875. [CrossRef]

26. Senaratna, T.; Touchell, D.; Bunn, E.; Dixon, K. Acetyl Salicylic Acid (Aspirin) and Salicylic Acid Induce Multiple Stress Tolerance in Bean and Tomato Plants. Plant Growth Regul. 2000, 30, 157-161. [CrossRef]

27. Tari, I.; Csiszar, J.; Gabriella, S.; Horvath, F.; Pecsvaradi, A.; Kiss, G.; Szepsi, A.; Szabo, M.; Erdei, L. Acclimation of Tomato Plants to Salinity Stress after a Salicylic Acid Pre-treatment. Acta Biol. Szeged. 2002, 46, 55-56.

28. Szepesi, A.; Csiszar, J.; Bajkan, S.; Gemes, K.; Horvath, F.; Erdei, L.; Deer, A.K.; Simon, M.L.; Tari, I. Role of Salicylic Acid Pre-treatment on the Acclimation of Tomato Plants to Salt- and Osmotic Stress. Acta Biol. Szeged. 2005, 49, $123-125$.

29. Yildirim, E.; Dursun, A. Effect of Foliar Salicylic Acid Applications on Plant Growth and Yield of Tomato under Greenhouse Conditions. Acta Hortic. 2009, 807, 395-400. [CrossRef]

30. Gharib, F.A. Effect of Salicylic Acid on the Growth, Metabolic Activities and Oil Content of Basil and Marjoram. Int. J. Agric. Biol. 2006, 4, 485-492.

31. Kosalec, I.; Bakmaz, M.; Pepeljnjak, S.; Vladimir-Knezević, S. Quantitative Analysis of the Flavonoids in Raw Propolis from Northern Croatia. Acta Pharm. 2004, 54, 65-72.

32. Ahn, M.R.; Kunimasa, K.; Ohta, T.; Kumazawa, S.; Kamihira, M.; Kaji, K.; Uto, Y.; Hori, H.; Nagasawa, H.; Nakayama, T. Suppression of Tumor-Induced Angiogenesis by Brazilian Propolis: Major Component Artepillin C Inhibits In Vitro Tube Formation and Endothelial Cell Proliferation. Cancer Lett. 2007, 252, 235-243. [CrossRef] [PubMed]

33. Kocot, J.; Kiełczykowska, M.; Luchowska-Kocot, D.; Kurzepa, J.; Musik, I. Antioxidant Potential of Propolis, Bee Pollen, and Royal Jelly: Possible Medical Application. Oxidative Med. Cell. Longev. 2018, 7074209. [CrossRef] [PubMed]

34. Havsteen, B.H. The Biochemistry and Medical Significance of Flavonoids. Pharmacol. Ther. 2002, 96, 67-202. [CrossRef]

35. Santos, V.R. Propolis: Alternative Medicine for the Treatment of Oral Microbial Diseases. In Alternative Medicine; Sagakami, H., Ed.; InTechOpen: Rijeka, Croatia, 2018; pp. 133-169. [CrossRef]

36. Salman, S.R.; Abou-hussein, S.D.; Abdel-Mawgoud, A.R.; El-Nemr, M.A. Fruit Yield and Quality of Watermelon as Affected by Hybrids and Humic Acid Application. J. Appl. Sci. Res. 2005, 1, 51-58.

37. Eshghi, S.; Garazhian, M. Improving Growth, Yield and Fruit Quality of Strawberry by Foliar and Soil Drench Applications of Humic Acid. Iran Agric. Res. 2015, 34, 14-20. [CrossRef]

38. Pobiega, K.; Przybył, J.L.; Żubernik, J.; Gniewosz, M. Prolonging the Shelf Life of Cherry Tomatoes by Pullulan Coating with Ethanol Extract of Propolis during Refrigerated Storage. Food Bioprocess Technol. 2020, 13, 1447-1461. [CrossRef]

39. Guginski-Piva, C.A.; Santos, D.; Idalmir, W.; Júnior, A.; Winter, H.; Daniel, F.; Flores, M.; Pazolini, K. Propolis for the Control of Powdery Mildew and the Induction of Phytoalexins in Cucumber. Idesia 2015, 33, 39-47. [CrossRef]

40. Weidner, S. Role of Gibberellins and Cytokinins in the Regulation of Germination during Development and Ripening of Triticale caryopses L. Acta Soc. Bot. Pol. 1984, 53, 257-270. [CrossRef]

41. Zhaoliang, L.; Yueqing, S.; Minzhi, S.; Yahong, S. Effect of Paclobutrazol (PP333) on Plant Histological Structures of Some Crops Shanghai Nongye Xuebao. Acta Agric. Shanghai 1995, 11, 43-47.

42. Semida, W.M.; Rady, M.M. Presoaking Application of Propolis and Maize Grain Extracts Alleviates Salinity Stress in Common Bean (Phaseolus vulgaris L.). Sci. Hortic. 2014, 168, 210-217. [CrossRef]

43. Walker, P.; Crane, E. Constituents of Propolis. Apidologie 1987, 18, 327-334. [CrossRef]

44. Bankova, V.S.; De Castro, S.L.; Marucci, M.C. Propolis: Recent Advances in Chemistry and Plant Origin. Apidologie 2000, 31 , 3-15. [CrossRef]

45. Chandra, A.; Anand, A.; Dubey, A. Effect of Salicylic Acid on Morphological and Biochemical Attributes in Cowpea. J. Environ. Biol. 2007, 28, 193-196. [PubMed]

46. Sayyari, M.; Babalar, M.; Kalantari, S.; Serrano, M.; Valero, D. Effect of Salicylic Acid Treatment on Reducing Chilling Injury in Stored Pomegranates. Postharvest Biol. Technol. 2009, 53, 152-154. [CrossRef] 
47. Hao, W.; Guo, H.; Zhang, J.; Hu, G.; Yao, Y.; Dong, J. Hydrogen Peroxide Is Involved in Salicylic Acid-Elicited Rosmarinic Acid Production in Salvia miltiorrhiza Cell Cultures. Sci. World J. 2014, 843764. [CrossRef]

48. Mora-Herrera, M.E.; Peralta-Velázquez, J.; López-Delgado, H.A.; García-Velasco, R.; González-Díaz, J.G. Efecto del Ácido Ascórbico Sobre Crecimiento, Pigmentos Fotosintéticos y Actividad Peroxidasa en Plantas de Crisantemo. Rev. Chapingo Ser. Hortic. 2011, 17, 73-81. [CrossRef]

49. Kord, M.; Hathout, T. Changes on Some Growth Criteria, Metabolic Activities and Endogenous Hormones in Tomato Plants Consequent to Spraying with Different Concentrations of Salicylaldehyde. Egypt J. Physiol. Sci. 1992, 16, 117-139.

50. El-Yazal, M.A.S. Impact of Propolis Extract as Foliar Spray on Growth, Yield and Some Chemical Composition of Spinach (Spinacia oleracea L.) Plants Grown under Calcareous Saline Soil. Int. J. Empir. Educ. Res. 2019, 3, 1-14. [CrossRef]

51. Chakraborty, U.; Pradhan, D. High Temperature-Induced Oxidative Stress in Lens culinaris, Role of Antioxidants and Amelioration of Stress by Chemical Pre-treatments. J. Plant Interact. 2011, 6, 43. [CrossRef]

52. Garbero, M.; Pedranzani, H.; Zirulnik, F.; Molina, A.; Pérez-Chaca, M.; Vigliocco, A.; Abdala, G. Short-Term Cold Stress in Two Cultivars of Digitaria eriantha: Effects on Stress-Related Hormones and Antioxidant Defense System. Acta Physiol. Plant 2011, 33 , 497-507. [CrossRef]

53. Li, T.; Hu, Y.; Du, X.; Tang, H.; Shen, C.; Wu, J. Salicylic Acid Alleviates the Adverse Effects of Salt Stress in Torreya grandis cv. Merrillii Seedlings by Activating Photosynthesis and Enhancing Antioxidant Systems. PLoS ONE 2014, 9, e109492. [CrossRef] [PubMed]

54. El-Esawi, M.A.; Elansary, H.O.; El-Shanhorey, N.A.; Hamid, A.; Mohamed, A.; Ali, H.M.; Elsheikh, M.S. Salicylic Acid Regulated Antioxidant Mechanisms and Gene Expression Enhance Rosemary Performance under Saline Conditions. Front. Physiol. 2017, 8, 716. [CrossRef] [PubMed]

55. Hayat, S.; Hasan, S.A.; Fariduddin, Q.; Ahmad, A. Growth of Tomato (Lycopersicon esculentum) in Response to Salicylic Acid under Water Stress. J. Plant. Interact. 2008, 3, 297-304. [CrossRef]

56. Bankova, V.; Popov, S.; Manolova, N.; Maximova, V.; Gegoug, G.; Serkedjieva, J.; Auzunov, S. The Chemical Composition of Some Propolis Fractions with Antiviral Action. Acta Microbiol. Bulg. 1988, 23, 52-57. [PubMed]

57. Scheller, S.; Wilczok, T.; Imielski, S.; Krol, W.; Gabrys, J.; Shani, J. Free Radical Scavenging by Ethanol Extract of Propolis. Int. J. Radiat. Biol. 1990, 57, 461-465. [CrossRef] [PubMed]

58. Noweer, E.M.A.; Dawood, M.G. Efficiency of Propolis Extract on Faba Bean Plants and Its Role against Nematode Infection. Comm. Appl. Sci. 2009, 74, 593-603.

59. Salama, M.I.; Elaidy, A.A.; El-Sammak, A.; Abou-Khashab, A.M. Leaf Pigment and Nutrient Element Content of Roumi Red Grape Nurslings as Affected by Salinity and Some Growth Regulators. Tanta J. of Agric. Res. 1992, 18, $382-391$.

60. Adil, W.; Ahlam, M.; Muneeb, R.; Seema, A.; Hussain, M. Bee Propolis (Bee's Glue): A Phytochemistry Review. J. Crit. Rev. 2017, 4, 9-13. [CrossRef]

61. Climate Alexandria. Available online: https://en.climate-data.org/africa/egypt/alexandria-governorate/alexandria-515/ \#climate-graph (accessed on 13 February 2020).

62. Khan, W.; Prithiviraj, B.; Smith, D.L. Photosynthetic Responses of Corn and Soybean to Foliar Application of Salicylates. J. Plant Physiol. 2003, 160, 485-492. [CrossRef]

63. Hull, H.M.; Morton, H.L.; Wharrie, J.R. Environmental Influence on Cuticle Development and Resultant Foliar Penetration. Bot. Rev. 1975, 41, 421-452. [CrossRef]

64. Abo-elyousr, K.; Selaim, M.A.; El-Sharkawy, R.M.; Bagy, H.M.M.K. Effectiveness of Egyptian Propolis on Control of Tomato Bacterial Wilt Caused by Ralstonia solanacearum. J. Plant Dis. Prot. 2017, 124, 467-472. [CrossRef]

65. Taha, S.S.; Osman, A.S. Influence of Potassium Humate on Biochemical and Agronomic Attributes of Bean Plants Grown on Saline Soil. J. Hortic. Sci. Biotechnol. 2018, 93, 545-554. [CrossRef]

66. Association of Official Analytical Chemists (AOAC). Official Methods of Analysis, 15th ed.; AOAC: Arlington, VA, USA, 1990. [CrossRef]

67. Lichtenthaler, H.K. Chlorophylls and Carotenoids: Pigments of Photosynthetic Biomembranes. Methods Enzymol. 1987, 148, 350-382. [CrossRef]

68. Singleton, V.L.; Orthofer, R.; Lamuela-Raventos, R.M. Analysis of Total Phenols and Other Oxidation Substrates and Antioxidants by Means of Folin-Ciocalteu Reagent. Methods Enzymol. 1999, 299, 152-178. [CrossRef]

69. Ordoñez, A.A.L.; Gomez, J.G.; Vattuone, M.A.; Isla, M.I. Antioxidant Activities of Sechium edule (Jacq.) Swart Extracts. Food Chem. 2006, 97, 452-458. [CrossRef]

70. Bradford, M.M. A Rapid and Sensitive Method for the Quantitation of Microgram Quantities of Protein Utilizing the Principle of Protein-Dye Binding. Anal. Biochem. 1976, 72, 248-254. [CrossRef]

71. Giannopolitis, C.N.; Ries, S.K. Superoxide dismutases I. Occurrence in Higher Plants. Plant Physiol. 1977, 59, 309-314. [CrossRef]

72. Aebi, H. Catalase In Vitro. Methods Enzymol. 1984, 105, 121-126. [CrossRef]

73. Thomas, R.L.; Jen, J.J.; Morr, C.V. Changes in Soluble and Bound Peroxidase, IAA Oxidase during Tomato Fruit Development. J. Food Sci. 1982, 47, 158-161. [CrossRef] 